\title{
Ways of Seeing Christ the Judge: The Iconography of Christ III and its Visual Context
}

\author{
Natalie Jones ${ }^{1} \mathbb{D}$
}

Accepted: 18 January 2021 / Published online: 25 February 2021

(C) The Author(s) 2021

\begin{abstract}
This article examines the iconographic programme of the Last Judgement scene depicted in Christ III. A notable feature of the poem's detailed visual programme is the way in which it provides the audience with a single, panoramic vision that encompasses the divergent perspectives of the blessed and the damned. It is on account of this dual perspective that the poem, through its precise use of language and imagery, presents the audience with a bifocal vision of Christ as King of Kings and Judge of the World, in keeping with the words of Revelation 19:16. A detailed analysis of the poem's imagery, however, suggests that its portrait of Christ as Judge is not only informed by scripture and exegetical sources, but is also indebted to contemporary visual imagery, particularly the depiction of Christ as Majestas Domini, or Christ in Majesty. As a result, and by approaching the poem's imagery from an iconological perspective, it is argued that the poet of Christ III had a detailed knowledge of contemporary Christological motifs. Furthermore, a careful analysis of the language used to describe the Judgement scene, and particularly the depiction of Christ as Judge, suggests that the poet intentionally seeks to evoke a range of specific visual images in the mind of his audience in order to amplify the poem's instructive and penitential aims.
\end{abstract}

Keywords Christ III · Last judgement · Christ as judge · Eschatology · Iconography $\cdot$ Penitence

Although many Old English works explore the theme of the Last Judgement, the iconographic programme and the almost eidetic emphasis on the depiction of scriptural events so evident in Christ III make it a particularly striking piece. Indeed, scholars have often recognized the unparalleled vivacity of the eschatological vision presented in the poem; for instance, writing in 1982, S.A.J. Bradley (1982, p. 229)

Natalie Jones

natalie.jones@ucl.ac.uk

1 Department of English Language and Literature, University College London, Gower Street, London WC1E 6BT, UK 
observed that the poet's vivid account of the Last Judgement 'appeals powerfully to the emotions and to the visual imagination', while more recently Bernard J. Muir (2000, p. 418) stated that 'The poem is the most detailed poetic exposition of the "Last Judgement" among the surviving poetry'. Yet even though the visual quality of Christ III has long been praised, scholarly interest has traditionally focused largely on unpicking the poem's exegetical sources and thus establishing its undeniably learned background, rather than engaging directly with the poem's visual context and use of Christian iconography (a tradition which is, in turn, heavily indebted to scripture and exegesis). In recent times the visual qualities of the poem have been more fully recognized and, in particular, much has been written on the emphasis on vision in the poem's account of the Judgement scene; for example, Thomas Hill (1973), Sachi Shimomura (2002), and Timothy Arner and Paul Stegner (2007) have all noted the stress placed on ways of seeing in the poem and have commented at length on the distinctive perspectives of the blessed and the damned. However, while this emphasis on vision is certainly pivotal to the poem's narrative, an analysis of its detailed iconographic programme reveals that the act of looking also extends beyond the boundary of the text itself, as the audience is granted a panoramic vision which encompasses the blessed and the damned simultaneously. In carefully constructing this conceptual line of vision, the poet presents the audience with a number of detailed and familiar iconographic portraits of Christ as Judge which act as a powerful vehicle for instruction: just as the blessed and the damned in the poem learn through what they see so, too, do the audience through their privileged perspective. As a consequence, and as this study will demonstrate, the link between the act of looking and the acquisition of knowledge is one of primary importance in Christ $I I I$, as the poem's careful use of language and description works to recall a number of established iconographic motifs that are deployed intentionally for a didactic purpose and are often informed by the visual arts. By considering the poem's imagery, and specifically its depiction of Christ, from an iconological perspective, the discussion which follows seeks to uncover further the nexus of scripture, exegesis, and iconography which underpins Christ III: in so doing, it not only demonstrates the author's familiarity with a range of contemporary Christological motifs found in both the exegetical and iconographic traditions but, more significantly, it suggests that the poem actively evokes a range of specific visual images in the mind of its audience in order to amplify its instructive and penitential aims.

Before turning to examine the imagery of Christ III in detail, it is useful to begin with a consideration of the poem's wider visual context, particularly with regard to the prevalence of Last Judgement iconography and the depiction of Christ as Judge. As Barbara Raw (2004, pp. 104-5) has noted, a consideration of the variety of contexts in which religious imagery survives suggests that images of the divine had a wide currency in Anglo-Saxon England and were thus readily familiar. Although full-scale narrative scenes of the Last Judgement did not emerge until the twelfth century, it is clear that an Anglo-Saxon audience would be well-versed in the iconography of the Last Judgement as discrete episodes from the Apocalypse, and especially the depiction of Christ as Judge can be found across a number of artistic mediums. For instance, in addition to a significant number of manuscript illustrations, which would often have been encountered by a more limited audience, images 
of Christ as Judge are frequently depicted on the freestanding crosses that were on public display and used both to mark a place of Christian worship and as preaching aids. The carvings on both the Bewcastle and Ruthwell crosses, for example, depict the image of Christ as Judge and Saviour, treading on the beasts, in accordance with Vulgate Psalm 90. ${ }^{1}$ It is also likely that contemporary audiences could have encountered eschatological motifs through the interior of churches. Indeed, in his Historia abbatum Bede reports that a significant number of religious paintings were brought back from Rome by Benedict Biscop and hung in the churches at Wearmouth and Jarrow; according to Bede, these panel paintings presented a variety of narrative and conceptual images, including scenes from the Last Judgement (Plummer 1961, I, pp. 369-70). ${ }^{2}$ Although Bede's account makes specific reference to panel paintings, the Last Judgement also seems to have been a popular subject for the wall paintings which would have decorated the interior of at least some late Anglo-Saxon churches. In spite of the paucity of the surviving evidence, David Park (1984, p. 213) has suggested that the fragments which do survive 'may have formed part of Last Judgement compositions'. The fragment from Winchester Cathedral, for example, which most likely dates to the tenth century, depicts a group of three human figures and possibly formed part of a larger image of Christ enthroned in Majesty, surrounded by the adoring faithful (Wormald 1967, p. 162). Similarly, the tenth-century fragment at St Andrew's Church, in Nether Wallop, Hampshire, shows two winged angels raising what appears to be part of a mandorla, which may have originally nimbed the enthroned Christ (Gem and Tudor-Craig 1980). A more extensive range of Last Judgement iconography is preserved in the remains of a series of wall paintings in St Mary's Church, Houghton-on-the-Hill, near Swaffham in Norfolk. Typically thought to be the earliest surviving examples in England, these large-scale wall paintings date to the very late Anglo-Saxon period, or to the years immediately following the Norman Conquest. Although the fragments on the east wall of the church are most notable for the fact that they preserve one of the earliest depictions of the Trinity as the Gnadenstuhl or Throne of Grace, the painting is also significant for its preservation of early eschatological motifs; immediately surrounding the triune Godhead are images of the heavenly host and, in the lower left corner, an angel blows a trumpet to raise the souls of mankind from their tombs. Although many parts of the painting are now lost, it seems reasonable to suggest that the central image of the Throne of Grace was originally surrounded by scenes of the Last Judgement and the fates of the blessed and the damned. ${ }^{3}$ Indeed, the well-known Lewes Group of Anglo-Norman wall paintings, which date to $c .1080-1120$ and derive much of their Last Judgement iconography from Anglo-Saxon examples, might be seen as later examples of an earlier tradition. ${ }^{4}$

\footnotetext{
1 On the treatment of this motif in these two examples, see Ó Carragáin (1981, pp. 377-403). See also Ó Carragáin (2012, pp. 367-83), who notes that these panels also evoke Christ's Second Coming.

2 On the paintings at Wearmouth and Jarrow, see Meyvaert (1979, pp. 63-72).

3 See details of the painting as described in the conservation report by Curteis (2006, p. 3).

4 This later tradition, commonly known as the Lewes Group of wall paintings, has been discussed in full by Park (1984, p. 213).
} 
Although the forms and mediums in which religious imagery survives remind us that it could serve a number of possible functions, the public display of Last Judgement iconography highlights the prevalence of, and an audience's potential familiarity with, certain eschatological motifs. The importance ascribed to these motifs in the iconographic programmes of Anglo-Saxon art finds an interesting parallel in the literary tradition where, as Christ III demonstrates, the same range of narrative images and iconographic types were also evoked. Indeed, by exploiting the visual potentialities of the written word, Anglo-Saxon authors could break down the finite boundaries of the static image and thus engage and instruct their audience more forcefully. Although Christ III is clearly the work of a skilled author in this respect, it is worth noting the many unanswered questions regarding its authorship and audience. As is well known, Christ III is one in a series of three Christological poems preserved in the Exeter Book and has traditionally been attributed to the poet Cynewulf, although this attribution is now generally eyed with a good deal of caution, if not rejected entirely. The origins and provenance of the Exeter Book are an ongoing topic of debate among scholars and various locations have been suggested as its likely place of production, including Glastonbury, Exeter, Crediton and Christ Church, Canterbury. ${ }^{5}$ Due to these likely places of origin, the Exeter Book has been linked to a religious or monastic community and has often been considered a product of the Benedictine Reform. ${ }^{6}$ However, some of its material, particularly the riddles, might be more indicative of a clerical milieu rather than an exclusively monastic context (Butler 2001, pp. 197-98). The book's varied content might also suggest that it may not have been composed for a specific purpose, other than the personal function it would have served for the compiler. However this might be, the skilful depiction of the Last Judgement in Christ III reveals that its author not only has an impressive command of exegetical sources, ${ }^{7}$ but that he repeatedly relies on a shared understanding of religious iconography in order to communicate his message to the audience. Indeed, the careful terminology used to describe the Judgement scene, and particularly the depiction of Christ as Judge, suggest that the author has in mind, and is intentionally seeking to evoke, certain iconographic motifs and gestures.

The author's subtle evocation of contemporary iconographic motifs is evident from the early stages of Christ III. Prior to its focus on the depiction of Christ, the poem begins by establishing a conventional iconographic tableau of Doomsday, presenting a vivid description of the so-called signs of the coming Judgement which mark 'se micla dæg meahtan dryhtnes' ('the great day of the mighty Lord') (Muir

\footnotetext{
${ }^{5}$ Conner (1993a) has put forward the strongest case for an Exeter provenance for the Exeter Book; this view has been supported by Muir (2000, p. 3), who has suggested that the book originates most likely from either Exeter or Crediton. Butler (2001) suggests a Glastonbury origin, while Gameson (1996) also contests the Exeter provenance. He acknowledges that both Glastonbury and Crediton are valid possibilities, but concludes that the origin of the book is ‘best considered unknown' (p. 179).

6 The possible connection between the production of the Exeter Book and the Benedictine Reform has been widely discussed. See Conner (1993a, pp. 148-50) and (1993b); Salvador (2006, pp. 169-212); Drout (2007, pp. 447-66).

7 See further Biggs (1989-1990).
} 
2000, 1. 869). ${ }^{8}$ Although the poet emphasizes the suddenness of the coming Judgement, the beginning of the scene is marked by a number of established eschatological portents, including angels sounding trumpets to wake the dead (11. 878-81; 886-89), surging fire and noise (11. 930-33; 964-70), and companies of angels and devils (11. 892-98). ${ }^{9}$ These motifs are well established, having their origins in the accounts of the Last Judgement in Matthew (24:29-31 and 25:31-46) and the Book of Revelation, ${ }^{10}$ as well as the popular apocryphal work, the Apocalypse of Thomas, which offers a list of the signs of judgement in its account of the end of the world in seven days. ${ }^{11}$ It is also worth noting that some of the features described in the poem, such as the gathering of the Elect on Mount Sion (11. 875-77), may have been more directly informed by Irish sources (Biggs 1989-1990; Hall 1993). While the visual power of the opening scene is evident through the poem's detailed use of language, it is further heightened by the fact that some of the motifs described by the poet also lend themselves well to pictorial expression. Indeed, the motif of angels sounding trumpets was especially popular, found in both manuscript illustration and wall painting, as evinced by the example at St Mary's Church, Houghton-on-the-Hill. ${ }^{12}$

Once the conventional portents of judgement have been introduced, the poet turns to focus on the iconography of the Parousia, or Second Coming of Christ, in more detail. Although the poet utilizes several iconographic types of the Saviour, the poem's opening depiction is most heavily informed by the concept of Christ as light, as the dominant focus is placed not on Christ's physical appearance but on the brilliant effulgence which radiates from him as he descends from heaven: we are told that the 'sunnan leoma / cymeð of scyppende' (11. 900-1; 'light of the sun / comes from the creator') and, 'beorhte blican' (1. 903; 'shining brightly'), it shines on Mount Sion:

Ponne semninga on Syne beorg.

supaneastan sunnan leoma.

cymeð of scyppende scynan leohtor.

ponne hit men mægen modum ahycgan,

beorhte blican, ponne bearn godes.

purh heofona gehleodu hider oðyweð.

Cymeð wundorlic Cristes onsyn,

æpelcyninges wlite, eastan fram roderum. (11 899-906).

(Then, suddenly, on Mount Sion,

from the southeast, the light of the sun

${ }^{8}$ All subsequent quotations in Old English are taken from Muir's edition (2000, pp. 79-107) and are embedded into the text, with line numbers given in parenthesis. Unless otherwise stated, all Old English translations are mine.

9 For a discussion of these features in the poem and their possible sources, see Hill (1971, pp. 691-98).

10 All Biblical quotations in Latin are taken from Weber (1994). All Bible quotations in English are taken from the Douay-Challoner translation of the Vulgate.

11 The Apocalypse of Thomas has been edited by Schneelmelchor and McL. Wilson (1991, I, pp. 798803). For the popularity of the work in an Old English context see Swan (1998, pp. 333-46).

12 An image of an angel holding a sceptre and trumpet is also found in the eleventh-century Gospel Book, Cambridge, Pembroke College, MS 301, fol. 3v; see James and Minns (1905, p. 263). 
comes from the creator, shining brighter

than men may devise in mind,

shining bright, when God's son

shall appear hither through heaven's vaults.

Christ's wonderful figure, the noble king's form,

will come from the East, from the skies).

This emphasis on Christ's 'scynan wlite' (1. 914; 'shining form') is further highlighted in lines 1007-13 where Christ, as the 'cyning heofonengla' (1. 1009; 'king of heaven's angels'), will 'scineð wuldorlic ofer weredum' (11. 1009-10; 'shine gloriously over the troops') as he appears with his heavenly company. The repeated and varied use of light imagery at this point serves to affirm Christ's divine sovereignty and his role as Saviour and Judge, while also establishing a contrast to the poem's opening where mankind is trapped in perpetual darkness and turmoil. The description of Christ's radiance is clearly designed to recall the Johannine tradition of Christ as the Light of the World (John 8:12) and is in keeping with scriptural treatments of Christ's appearance at the Last Judgement, where it is said that the Saviour radiates light in affirmation of his divinity: 'and they [the saved] shall not need the light of the lamp, nor the light of the sun, because the Lord God shall enlighten them' (Revelation 22:5).

In addition to evoking a chain of related, scriptural passages, the poem's focus on Christ's radiance at the Parousia also encourages the audience to visualise Christ in accordance with well-established iconographic traditions. Although contemporary artists deploy a number of motifs in order to denote Christ's luminescence, it is the mandorla, as a type of aureole (from the Latin aurea, or 'golden'), which serves as the standard iconographic motif used to symbolize the glorification of Christ, his mother, and his angels and saints. Indeed, the mandorla was a standard component of the popular, contemporary image of the Majestas Domini, or Christ in Majesty, which depicts Christ enthroned in glory as the exalted ruler of heaven and earth. ${ }^{13}$ This depiction of Christ was widely popular in both Western and Byzantine art and many of the early examples, particularly those produced in the East, had an imperial focus and denoted Christ's role as lawgiver, or pointed more particularly to Christ's divine kingship and his dominion over the cosmos. However, due to the description of the heavenly court in Revelation 4:1-11, which describes 'a throne set in heaven', the motif was also invested with eschatological significance and was thus understood, in certain iconographic contexts, to signify Christ's Second Coming and his future role as Judge. ${ }^{14}$ This scriptural context clearly accounts for the depiction of Christ enthroned in Majesty in an eighth-century ivory plaque of the Last Judgement, now in the Victoria and Albert Museum. Here, in keeping with the scene being evoked in Christ III, the upper registers of the plaque depict Christ nimbed by a mandorla and placed above the Judgement scene; he is flanked by angels who

\footnotetext{
13 This iconographic motif has its origins in a number of scriptural passages, including the prophetic visions of the enthroned Lord as described in Isaiah 6:1-4 and Ezekiel 1:1-28 which, in turn, found fulfilment in the description of the heavenly court in Revelation 4:1-11.

14 See further Schiller (1971, pp. 233-45).
} 
sound their trumpets while, on the middle register of the plaque, the dead rise out of their tombs. ${ }^{15}$ Although this ivory is unlikely to be of Anglo-Saxon provenance, ${ }^{16}$ the importance of Christ's radiance at the Second Coming, symbolised by the mandorla, is also evident in the illustration of the Parousia preserved in the tenth-century Benedictional of Æthelwold (London, British Library, MS Additional 49,598, fol. 9v). ${ }^{17}$ Just as Christ III seeks to describe the moment when 'bearn godes / purh heofona gehleodu hider oðyweð' (1l. 903-4; 'God's son shall appear hither through heaven's vaults'), this image, unusual in its iconography, presents Christ striding down to earth, nimbed by a mandorla and bearing a staff. He is followed by a host of angels who hold the Cross aloft and the words of Revelation 19:16, 'Rex regum et Dominus dominatium' ('King of Kings and Lord of Lords') are written on his robe in order to confirm to the viewer Christ's future role as Judge.

Although the iconographic depiction of Christ nimbed by a mandorla may well have informed the audience's visualisation of the Saviour at this point in the poem, Christ III also evokes a strand of complementary scriptural passages and exegesis. Indeed, in addition to recalling the popular Johannine tradition of Christ as the 'light of the world', the poem's emphasis on Christ's radiance also evokes the prophetic description of the Sol Justitiae, or Sun of Justice, from Malachi 4:2: 'But unto you that fear my name, the Sun of justice shall arise'. The evocation of the Sol Justitiae in an eschatological context is evident in the early exegetical tradition, where the light of Christ as the 'Sun of Justice' is linked to the Parousia and Christ's role as judge. For instance, in his Commentaries on Malachi, the fourth-century Bishop of Cyrrhus, Theodoret, argued that the Sol Justitiae applies to both the first and second coming of Christ:

Nam in priori quidem, velut sol quispiam nobis exortus est, in caligine et umbra mortis constitutis, atque a peccato nos liberans ... Et in secundo rursus adventu his qui in hac vita vexantur, vel ex eorum voto vel praeter eorum votum appareus ... Et quemadmodum sol sensibilis exoriens somno oppressos ad laborem excitat: sic his adveniens longo somno id est morte, constrictos excitat. (Interpretatio Malachiae Prophetae 4; Migne 1864, PG 81, cols. 1983-86). ${ }^{18}$

The utilization of the Sol Justitiae in an exclusively eschatological context is also frequently found in the writings of Augustine, where the words of Malachi 4:2 are

\footnotetext{
${ }^{15}$ Last Judgement, ivory relief. Southern German or Northern Italian (c.800, Victoria and Albert Museum, London).

16 The origins of this plaque have been debated. Beckwith (1972, p. 22, p. 118) argued for an AngloSaxon provenance, although it is now generally considered to be a product of a continental workshop; see Williamson (2010, pp. 152-53).

17 The Benedictional of Æthelwold has been discussed at length by Deshman (1995).

18 'In the first he rose like a kind of sun for us who were seated in darkness and shadow, freed us from $\sin$.... In the second coming for those worn out in the present life he will appear either in accord with their will or against it .... Just as the material sun in its rising awakens to work those in the grip of sleep, so in his coming he raises up those in the grip of the long sleep of death' (Ferreiro 2003, p. 311).
} 
cited in order to convey the symbolic nature of Christ's light at the Last Judgement. In the twentieth book of his De Civitate Dei, Augustine writes:

Haec distantia praemiorum atque poenarum iustos dirimens ab iniustis, quae sub isto sole in huius uitae uanitate non cernitur, quando sub illo sole iustitiae in illius uitae manifestatione clarebit, tunc profecto erit iudicium quale numquam fuit. (De Civitate Dei 20, 27; Dombart and Kalb 1955, CCSL 48, p. 751). ${ }^{19}$

That the poet of Christ III seeks to evoke this exegetical tradition is evident, given his repeated use of light to signify Christ's coming: 'sunnan leoma / cymeð of scyppende scynan leohtor / ponne hit men mægen modum ahycgan' (11. 900-2; 'the light of the sun comes from the creator, shining brighter than men may devise in mind'). ${ }^{20}$ The analogy between Christ's radiance and the sun is also evoked later in the poem when Christ is described as the 'scircyning' (1. 1152; 'shining king') and, later still, when we are told: 'pær is seo dyre dryhtnes onsien / eallum pæm gesælgum sunnan leohtra' (11. 1650-51; 'There is the beloved face of the Lord / brighter than the sun to all the blessed'). That Christ appears to the blessed as the Sol Justitiae is especially striking and stands in contrast to the damned, who are 'on peostre' (1. 1545; 'in darkness'). This distinction seems to have been popular in the exegetical tradition where the blessed are commonly described as bathed in light or, in accordance with the words of Matthew 13:43, shining in themselves, while the damned are condemned to darkness. Indeed, Basil of Caesarea compares the sinner at the Last Judgement to a blind man: 'Si hunc solem non consicere, caeco detrimentum est: quale est peccatori dispendium luce vera carere?' (Hexameron 6:1; Migne 1857, PG 29, col. 119). ${ }^{21}$ Similarly, in his Enarrationes in Psalmos, Augustine also notes that at the Last Judgement the glory of Christ as Sol Justitiae will not shine on the damned:

Et hic quis sol, nisi sol ille iustitiae, quem sibi non ortum impii plangent in die iudicii? Qui dicturi sunt in illo die: 'Ergo errauimus a uia ueritatis, et iustitiae lumen non luxit nobis, et sol non ortus est nobis'. Ei sol iste oritur, qui intellegit Christum. (Ennarationes in Psalmos 104:26; Dekkers and Fraipont 1956, CCSL 40, p. 1516)..$^{22}$

The poet of Christ III explicitly draws on this tradition in order to heighten the poem's instructive and penitential purpose: in addition to making Christ's divine nature manifest to the audience, the emphasis on divine effulgence also reminds

\footnotetext{
19 'When this wide gap between rewards and punishments, that cuts off the righteous from the unrighteous, and which we do not observe beneath this sun amid the vanity of this life, shall become glaring beneath that sun of righteousness in the revelation of that life, then surely shall there be such a judgement as there has never been' (Greene 1960, pp. 427-28).

20 The poet's utilization of the Sol Justitiae motif has also been noted by Shimomura (2002, pp. 48-49).

21 'If it is a loss to a blind man to be unable to look upon this [the sun], how great a loss is it to a sinner to be deprived of true light' (Way 1963, p. 85).

22 'Who is this sun? Surely the sun of righteousness whom the godless will bewail on the day of judgment, because it never rose for them. On that day they will lament, "No doubt of it, we strayed from the path of truth. On us the light of righteousness did not shine, nor did the sun rise for us." (Wis 5.6) But for the Church that sun does rise, for we understand the sun to be Christ' (Boulding 2003, V, p. 160).
} 
them of the coming Judgement and the glorified status of the blessed, who walk in the light of Christ, rather than in the darkness.

In order to heighten the prospect of the coming Judgement, the poem also encourages the audience to visualise Christ's Cross, which is depicted as a shining portent of Christ's coming in lines 1081-1114. Although the Cross was commonly understood as a triumphant sign of Christ's victory over death, the words of Matthew $24: 30$, which describe how the 'sign of the Son of man' will appear in the sky at the time of Judgement, invested the Cross with eschatological import. ${ }^{23}$ As Jennifer O'Reilly (1987-1988, pp. 84-88) has observed, the Cross's eschatological significance was further reinforced by the well-established typology which linked the Crucifixion of Christ with the Parousia, as revealed by the words of John 19:37 (which, in turn, echo the prophetic words of Zachariah 12:10), 'They shall look on him whom they pierced', and Revelation 1:7, 'Behold, he cometh with the clouds, and every eye shall see him, and they also that pierced him'. As a result of this exegesis, the Cross was a standard motif in Last Judgement iconography as it affirmed Christ's role as divine Saviour, confirming his promise to return in Judgement. The image of the Parousia in the Benedictional of Æthelwold clearly elucidates the significance of the Cross as an eschatological motif: the angelic host, who appear in the top left corner of the image and follow Christ, are led by an angel who holds the Cross aloft. The Cross is also a feature of two illustrations of Christ in Majesty in the wellknown Athelstan Psalter (London, British Library, MS Cotton Galba A XVIII). ${ }^{24}$ Although the two images have notable differences, they both depict Christ enthroned and surrounded by the heavenly host: in the image on folio $2 \mathrm{v}$ the Cross appears behind the left shoulder of Christ and is depicted alongside other instruments of the Passion; in the later image, on folio 21r, Christ himself holds the Cross as a sign of reproach and as a reminder of his sacrifice. In accordance with these examples, Christ III states that the Cross will shine in the sky and will serve as a 'prea' (1. 225; 'rebuke') to sinners; we are told that the 'hea rod / ryht aræred rices to beacne' (ll. 1064-65; 'high cross, was raised upright, as a sign of power'). In parallel to the earlier description of Christ's radiance, particular attention is given to the light which emanates from the Cross, as it is both the 'beacna beorhtast' (1. 1085; 'brightest of signs') and the 'leohta beam' (1. 1089; 'radiant tree'), which, like Christ as Sol Justitiae, shines on the heavenly multitude: 'sio reade rod ofer ealle / swegle scineð on pære sunnan' (1l. 1101-2; 'the red cross shines brightly over all, instead of the sun'). While this description of the bright, shining cross may recall the crux gemmata, the motif of the jewelled cross found in Byzantine art, the poet is careful to note that the Cross is not just shining but is 'blode bistemed' (1. 1085; 'moistened with blood'). This detail ensures that the divine effulgence which radiates from the Cross is balanced by a reminder of Christ's humanity and Passion. In spite of this, however, in

\footnotetext{
${ }^{23}$ Most notably, the treatment of the Cross as a sign of victory is encountered in The Dream of the Rood; see Krapp (1932, pp. 61-65).

24 This manuscript, originally a Carolingian production of the ninth century, reached England in the early tenth century. It includes two additional quires of West Saxon origin, inserted into the manuscript after it arrived in England, which contain a metrical calendar as well as at least five full-page images (one of which is now lost). See Deshman (1997, pp. 109-38) and Keynes (1985, pp. 193-98).
} 
the context of Christ III the Cross does not inspire compassion, so much as fear and repentance. Indeed, by mediating the description of the Cross through the eyes of the damned, the poet heightens the audience's visual and emotional response to the scene: they are reminded that the Cross signals the coming terror of Christ's judgement, particularly for sinners who will 'sorgum wlitað' (1. 1104; 'gaze with sorrow') on the Cross and find no consolation.

Following the description of the Cross, the poem turns to focus on the judgement scene from the respective perspectives of the blessed and the damned in more detail. Although these climactic episodes draw on a range of apocalyptic motifs, the energy in the judgement scene is underscored by the poem's depiction of Christ as Judge. The poet emphasizes this role repeatedly throughout the early stages of the poem; for instance, Christ is the 'mægencyninga meotod' (1. 942; 'lord of mighty kings'); the 'wuldorcyning' (1. 1022; 'king of glory'), the 'heofona cyning' (l. 1038; 'king of heaven'); and the 'sigedeman' (1. 1060; 'triumphant judge'). These descriptions reach their apogee in lines 1204-21, where Christ is seated in judgement before the damned. Lines 1216-20 are particularly compelling, encouraging the visualization of Christ enthroned as Judge:

ponne Crist siteð on his cynestole,

on heahsetle, heofonmægna god,

fæder ælmigtig. Folca gehwylcum,

scyppend scinende scrifeð bi gehwylcum.

eall æfter ryhte rodera waldend. (11. 1216-20).

(Then Christ will sit on his royal seat, on the high seat,

the seat of justice, god of the heavenly powers,

Father Almighty. To every one of the people

the shining creator will pass judgement by deeds,

all according to justice, Ruler of the Skies.)

The language used to describe Christ's throne is especially noteworthy, as it is presented as both a 'cynestole' (1. 1216; 'royal seat'), and a 'heahsetle' (1. 1217; 'high seat'), a term which can mean 'high seat, throne, seat of justice, and/or seat of honour' (Bosworth and Toller 1898-1921, 'heahsetle'). By placing Christ on a 'royal seat', which is also a 'high seat of justice', the poet directly communicates Christ's dual role as King of Kings and Judge of the World, in keeping with the description of the incarnate Word of God in Revelation 19:16. However, in light of the connotations of 'heahsetle' in particular, we can also interpret this as a subtle evocation of the words of 2 Corinthians 5:10 and the image of the 'judgement seat': 'For we must all be manifested before the judgement seat of Christ, that every one may receive the proper things of the body, according as he hath done, whether it be good or evil'. As a result of this, 'heahsetle' may recall the eschatological motif of the Etimasia, or prepared throne, which depicts the judgement seat of Christ in accordance with Vulgate Psalm 9:8-9: 'He hath prepared his throne in judgement: And he shall judge 
the world in equity, he shall judge the people in justice'. ${ }^{25}$ It is worth noting, however, that in iconographic terms the Etimasia was not a common feature of Western iconography and was, instead, a predominantly Eastern motif (Denny 1982, p. 538). Indeed, in Byzantine art, or in Western examples that were produced under Byzantine influence, the Etimasia is typically depicted as a seat or altar-like structure on which the Cross or a book is placed, representing the empty throne which Christ will assume on the Day of Judgement. ${ }^{26}$

Although it may be unlikely that the author of Christ III was familiar with the iconographic motif of the Etimasia, it seems clear we are intended to view the poem's reference to the 'heahsetle' (1. 1217) as the scriptural 'seat of judgement'. This is evinced by the poem's emphasis on justice, as we are told that Christ 'scrifeð' (1. 1219; 'will pass judgement on') the damned according to 'ryhte' (1. 1220; 'justice'). Indeed, the value ascribed to the 'heahsetle' at this point in the poem finds an interesting parallel in the exegetical tradition, where it was often noted that, at the time of Judgement, Christ would adopt a seated posture in order to confirm his role as ruler and judge. ${ }^{27}$ This idea has its origins in the writings of Gregory the Great and it is taken up by Ælfric, in his Homily on the Passion of St Stephen, where Christ's throne is understood not only as an affirmation of his role as Judge, but also as a symbol of his justice: 'Setl gedafenað deman. ... Nu andet ure geleafa cristes setll; for ðan pe he is se soða dema lybbendra 7 deadra' (Clemoes 1997, p. 201). ${ }^{28}$ When we consider the poem's depiction of Christ's throne in these terms, it is clear that the audience is directed to visualize a very particular type of Christ: this is not merely Christ as Judge, but an image of Christ as the Justus Judex, or Just Judge of the Old Testament, in accordance with Vulgate Psalm 7:9-12: 'The Lord judgeth the people. Judge me, O Lord, according to my justice ... God is a just judge, strong and patient'. The eschatological image that the poet conjures up once again finds a visual analogue in contemporary iconography. A particularly pertinent example of this mode of depiction is preserved in Cambridge, Trinity College, MS B.15.34, which dates to the eleventh century and contains a collection of Ælfric's homilies. This conceptual, contemplative image forms the frontispiece to the manuscript and presents Christ seated nimbed by a mandorla, raising his right hand in benediction and holding an open book in his left, which denotes his role as lawgiver. ${ }^{29}$ The words 'Iustus Iudex' are inscribed on Christ's breast, while at the bottom of his tunic are

\footnotetext{
${ }^{25}$ See the depiction of the throne of God in Revelation 20:11: 'And I saw a great white throne, and one sitting upon it, from whose face the earth and heaven fled away, and there was no place found for them'.

${ }^{26}$ On the iconography of the Etimasia, see Murray (1983, pp. 94-95); Hellemo (1989, pp. 103-12); Cherchi (1976, pp. 288-90).

${ }^{27}$ Gregory the Great observed that a seated posture was appropriate for a judge or ruler in his twentyninth homily on the Gospels: 'quia sedere judicantis est, stare vero pugnantis vel adjuvantis' (Migne 1857, PL 76, col. 1217). The significance of a seated posture is also discussed by Bede in his homily on the Easter Vigil (Martin and Hurst 1991, p. 62).

28 'A seat is becoming to a judge. ... Now our faith praises Christ's seat because he is the true judge of the living and the dead'. See also Ælfric's Homily on the Lord's Ascension (Clemoes 1997, p. 353), where this description of Christ's throne is repeated.

${ }^{29}$ Christ as Judge. Trinity College, MS B.15.34, fol. 1r (Cambridge, eleventh century). See Raw (1998, pl. 8).
} 
the words 'Rex Regum'. Here, as in Christ III, Christ is both 'King of Kings and Lord of Lords' who will 'judge and fight' with justice, in keeping with Revelation 19:11-16. The dual role of Christ highlighted in this image finds full expression in the poem's description of Christ as 'soðcyning', which is used in line 1228 and means 'king of truth or justice'.

The depiction of Christ enthroned as judge is undoubtedly key to the later stages of the poem and, through the author's careful use of language, is presented in a manner which subtly recalls contemporary iconographic traditions. However, although the image of Christ enthroned as judge is central to the poem's visual programme at this point, the poet is nonetheless careful to draw attention to the different aspects of Christ as Judge by manipulating ideas of perspective. As has often been noted, Christ III differentiates between the visions of the blessed and the damned in the judgement scene, specifically with regards to their perception of Christ. These divergent perspectives are established early on in the poem where we are told that Christ the Judge will be 'glædmod on gesihpe' (1. 910; 'joyful to behold') for the blessed, while for the damned he will be 'egeslic ond grimlic / to geseonne' (11. 918-19; 'fearful and terrible to see'). This difference in perspectives, which has its origins in the exegetical tradition and Gregory the Great's Moralia in Job (32.7.9; Adriaen 2005, CCSL 143, pp. 1635-36), ${ }^{30}$ becomes an increasingly important motif in the latter half of Christ III and is not only central to the penitential aims of the poem, but crucial to a consideration of its use of iconography.

As noted previously, the type of Christ that appears to the blessed adheres to the standard iconographic depiction of the enthroned Christ found in contemporary sources. As is evident in the image preserved in Cambridge, Trinity College, MS B.15.34, when artists chose to represent this iconographic type they typically sought to affirm its hieratic composition, depicting Christ enthroned, radiant, and showing no sign of his human suffering on the cross. These features are also evident in the image of Christ preserved on folio 2r of the Athelstan Psalter, where Christ is placed at the top of the image frame, seated on a throne above the heavenly host and nimbed by a mandorla. It is noteworthy that the sightline of the blessed in Christ III is in keeping with these iconographic examples: the poet draws attention to Christ's divine kingship and sovereignty, eschewing any focus on the wounds of the Passion. We are reminded of Christ's earlier appearance to the blessed as the 'mægencyning' (1. 916; 'powerful king') who has a 'scynan wlite' (1. 914: 'shining form'), and this hieratic vision is reaffirmed when Christ delivers his merciful speech to the saved. Here, Christ is the 'heofona heahcyning' (1. 1339; 'the high king of heaven') who 'wuldre scineð / of his heahsetle' (1. 1334: 'will shine in glory from his high seat'), addressing the blessed with words of comfort and mercy: 'halgan reorde / frefreð he

\footnotetext{
${ }^{30}$ Gregory writes 'sed tamen electis et reprobis nequaquam subspecie eiusdem incommutabilitatis ostenditur, quia et transquillus iustis, et iratus parebit iniustis'. A translation, given by Allen and Calder (1976, p. 96), reads: 'He will not appear to the saved in the same immutable form as to the damned, since He will seem calm to the just, but angry to the unjust'. The possible influence of this passage on the description in Christ III has been observed by Hill (1969, pp. 672-75).
} 
fægre ond him frip beodeð’ (11. 1339-40: 'with holy speech he will pleasantly console [them] and bid them peace').

Although the iconographic motif of the enthroned Christ, as seen by the blessed, would likely have been visually familiar to an Anglo-Saxon audience in the context of the visual arts, this type of Christ, as seen by the damned, is subtly modified. This Christ is 'egeslic ond grimlic / to geseonne' (11. 918-19; 'fearful and terrible to see'); his most significant attribute is that he displays 'pa ealdan wunde ond pa openan dolg' (1. 1107; 'the old wounds and the open scar'), which is particularly appropriate to sinners, in accordance with the prophetic words of John 19:37: 'They shall look on him whom they pierced'. ${ }^{31}$ This striking display of the Five Wounds, afforded exclusively to the damned, is most likely indebted to the exegetical tradition, as the motif was not an iconographic commonplace in the visual arts in England until the twelfth century when full-scale narrative scenes of the Last Judgement became popular. Yet, it is nonetheless worth noting that the motif does appear, albeit seldomly, in the art of the late Anglo-Saxon period, as the well-known example on folio $21 \mathrm{r}$ of the Athelstan Psalter attests. ${ }^{32}$ Here, the enthroned Christ raises his right hand as orans while wearing the exomis tunic, draped across one shoulder, which draws attention to the wound in his side. In order to underscore the eschatological import of the image, Christ carries the Cross in his left hand and the alpha and omega signs are positioned either side of his throne in order to recall the words of Revelation 1:8: 'I am Alpha and Omega, the beginning and the end, saith the Lord God, who is, and who was, and who is to come, the Almighty'. While we cannot be certain whether such an image would have been known to the poet of Christ III, it is clear that the motif was established and would have been familiar due to the words of Revelation 1:7, as well as the homiletic and patristic traditions (O'Reilly 1987-1988, pp. 73-74, p. 88). Indeed, for Anglo-Saxon authors in particular, the motif was widely known due to its inclusion in Caesarius of Arles' highly influential homily on the Last Judgement (sermo 57) which, as one of the principal sources of Christ III, directly informs Christ's commination of the damned in lines 1379-1523. In Caesarius' homily, Christ addresses mankind directly, reminding them of his Passion and displaying his wounds as a sign of reproach: 'En clavorum vestigia, quibus adfixus pependi; en perfossum vulneribus latus' (Morin 1953, CCSL 103, p. 253). ${ }^{33}$ This pathos gesture, known as the ostentatio vulnerum or 'displaying of the wounds', is found in Christ III, when Christ implores the damned, and thus by extension the audience, to contemplate his corporeal suffering ${ }^{34}$ :

\footnotetext{
31 On the tradition that Christ's wounds are not visible to the blessed, see Shimomura (2002, p. 46) and Hill (1973, p. 238).

32 Christ in Majesty with the heavenly host. British Library, MS Cotton Galba A. XVIII, fol. 21r (London, ninth century; additions added in the early tenth century). A second example is preserved on a late Anglo-Saxon ivory plaque in the Museum of Archaeology and Anthropology, Cambridge; see O'Reilly (1987-1988).

33 'Behold the imprints of the nails by which I hung affixed to the cross; behold My side pierced with wounds' (Mueller 1956, p. 284). The popularity of Caesarius as a patristic source during the AngloSaxon period has been demonstrated by Trahern Jr (1976, pp. 105-19).

34 Christ III is not the only Old English work to employ the ostentatio vulnerum motif, which was relatively commonplace in eschatological texts. See, for instance, the depiction of Christ bearing the wounds
} 
Geseoð nu pa feordolg pe ge gefremedun ær. on minum folmum ond on fotum swa some, purh pa ic hongade hearde gefæstnad; meaht her eac geseon orgete nu gen. on minre sidan swatge wunde. (1l. 1454-58).

(Now see the mortal wounds that you made before, on my hands and on [my] feet in the same way, through which I hung severely fastened; also here you might see manifest again now, a bloody wound in my side.)

In contradistinction to the later Middle Ages, the motif of Christ bearing the wounds in Judgement is invested here with theological, as opposed to devotional, significance and thus serves an instructive and penitential purpose. In the context of the poem, Christ's direct injunction to behold his wounds, vouchsafed to the damned alone, heightens the intensity of the audience's contemplation of Christ as Judge. The poet refines this line of vision in order to focus on Christ's corporeal suffering in detail; thus, the audience is forced to see Christ from the perspective of those who failed to repent in good time, which inspires contrition and repentance. This didactic potentiality is clearly exploited by the poet of Christ III, as the pathos gesture makes manifest the divine paradox of Christ's sacrifice at the hands of mankind, yet for mankind. As Christ observes in his commination of the damned: 'Ic onfeng pin sar pæt pu gesælig moste / mines epelrices eadig neotan' (ll. 1460-61; 'I took up your pain so that you may enjoy my native-realm, blessed and happy').

By allowing the audience to inhabit momentarily the divergent perspectives of the blessed and the damned in the judgement scene, Christ III grants its reader a bifocal vision which provides a profound, didactic lesson in repentance. The episode's sequence of binaries, which begins with the dual portraits of the enthroned Christ, before moving on to Christ's addresses to the blessed and the damned and their respective fates, repeatedly reminds the audience of the possible end which awaits their own souls, and which is determined by their acceptance or rejection of the sacrament of penance on earth. The wound displayed by the enthroned Christ exclusively to the damned functions as a didactic motif which inspires penitence in the audience so that, at the end of time, they may join the company of the blessed and see Christ, immaculate and radiant, enthroned in glory. This is borne out by the closing lines of the poem, which reaffirm the audience's desire for salvation by highlighting the rewards bestowed on the blessed. After the lengthy and detailed description of the torments of the damned and their consignment to hell (11. 1530-90), the poem concludes with a celebration of the state of paradisal joy enjoyed by the blessed: 'Đær is engla song, eadigra blis, / pær is seo dyre dryhtnes onsien / eallum

Footnote 34 (continued)

in judgement in Vercelli Homily XV (Scragg 1992, pp. 253-65, esp. p. 259) and an anonymous Old English homily written for Easter (Thomas 2017, pp. 57-72). 
pam gesælgum sunna leohtra' (11. 1649-51; 'There is the song of angels, the bliss of the blessed, there is the dear face of the Lord, brighter than the sun to all the blessed').

To conclude, an analysis of the iconographic programme of Christ III demonstrates that the poet's emphasis on ways of seeing extends beyond the account of the Last Judgement described in the poem itself. Through his precise use of language and imagery, the poet constructs a dynamic, visual scene for the audience, presenting a bifocal vision of Christ as King of Kings and Judge of the World, which is consistently informed by visual imagery. As we have seen, this visual programme enables the audience to conceptualize the doctrinal reality of death and judgement, heaven and hell, from the divergent perspectives of the blessed and the damned, which serves to inspire contrition and repentance. Thus, even though we are only capable of speculation regarding the possible contexts in which the poem was intended to be read, especially whether the poem was read aloud or with the use of ancillary visual aids, it is clear that visual imagery plays a vital role in conveying the moral purpose of the poem. This imagery not only characterises the journeys of the blessed and damned within the poem itself but is also crucial in conveying the poem's didactic agenda. Indeed, throughout Christ III ways of seeing and the visual perception of Christ as Judge are not only linked to the audience's acquisition of spiritual knowledge and understanding, but also facilitates the audience's journey towards repentance and salvation.

Open Access This article is licensed under a Creative Commons Attribution 4.0 International License, which permits use, sharing, adaptation, distribution and reproduction in any medium or format, as long as you give appropriate credit to the original author(s) and the source, provide a link to the Creative Commons licence, and indicate if changes were made. The images or other third party material in this article are included in the article's Creative Commons licence, unless indicated otherwise in a credit line to the material. If material is not included in the article's Creative Commons licence and your intended use is not permitted by statutory regulation or exceeds the permitted use, you will need to obtain permission directly from the copyright holder. To view a copy of this licence, visit http://creativecommons.org/licen ses/by/4.0/.

\section{References}

Adriaen, M. (Ed.). (1985). Gregorii Magni: Moralia in Iob. Corpus Christianorum Series Latina 143A-B. Turnhout: Brepols.

Allen, M. J. B., \& Calder, D. G. (1976). Sources and analogues of Old English poetry: The major Latin texts in translation. Cambridge: D.S. Brewer.

Arner, T., \& Stegner, P. (2007). 'Of pam aweaxeð wynsum gefea': The voyeuristic appeal of Christ III. Journal of English and Germanic Philology, 106(4), 428-446.

Beckwith, J. (1972). Ivory carvings in early medieval England. London: Harvey Miller and Medcalf.

Biggs, F. M. (1989-1990). The fourfold division of souls: The Old English Christ III and the insular homiletic tradition. Traditio, 45, 35-51.

Bosworth, J., \& Toller, T. N. (Eds.). (1898-1921). An Anglo-Saxon dictionary. London: Oxford University Press.

Boulding, M., (Trans.) \& Ramsay, B. (Ed.). (2000-2004). St Augustine: Expositions of the Psalms. 6 vols. New York: New City Press.

Bradley, S. A. J. (Ed. \& trans.). (1982). Anglo-Saxon poetry. London: Everyman. 
Butler, R. M. (2001). Glastonbury and the early history of the Exeter Book. In J. T. Lionarons (Ed.), Old English literature in its manuscript context (pp. 173-215). Morgantown, W.Va: West Virginia University Press.

Cherchi, P. A. (1976). Tradition and topoi in medieval literature. Critical Inquiry, 3, 281-294.

Clemoes, P. (Ed.). (1997). Alfric's Catholic Homilies: The first series. Early English Text Society s.s. 17. Oxford: Oxford University Press.

Conner, P. W. (1993a). Anglo-Saxon Exeter: A tenth-century cultural history. Woodbridge: Boydell.

Conner, P. W. (1993b). Source studies, the Old English Guthlac A and the English Benedictine Reformation. Revue Bénédictine, 103, 380-413.

Curteis, T. (2006). St Mary's Church, Houghton-on-the-Hill, Norfolk: Conservation of the wall paintings. Cambridge: Tobit Curteis Associates.

Dekkers, E., \& Fraipont, J. (Eds.). (1956). Augustine: Enarrationes in psalmos. Corpus Christianorum Series Latina 38-40. Turnhout: Brepols.

Denny, D. (1982). The last judgment tympanum at Autun: Its sources and meaning. Speculum, 57(3), 532-547.

Deshman, R. (1995). The Benedictional of Athelwold. Princeton: Princeton University Press.

Deshman, R. (1997). The Galba psalter: Pictures, texts and contexts in an early medieval prayerbook. Anglo-Saxon England, 26, 109-138.

Dombart, B., \& Kalb, A. (Eds.). (1955). Augustine: De civitate Dei. Corpus Christianorum Series Latina 47-48. Turnhout: Brepols.

Drout, M. D. C. (2007). Possible instructional effects of the Exeter Book 'wisdom poems': A Benedictine Reform context. In P. Lendinara, L. Lazzari, \& M. A. D’Aronco (Eds.), Form and content of instruction in Anglo-Saxon England in the light of contemporary manuscript evidence (pp. 447-466). Turnhout: Brepols.

Ferreiro, A. (Ed.). (2003). The twelve prophets. Ancient Christian commentary on scripture: Old Testament 14. Downers Grove, Illinois: Intervarsity Press.

Gameson, R. (1996). The origins of the Exeter book of Old English poetry. Anglo-Saxon England, 25, 135-185.

Gem, R., \& Tudor-Craig, P. (1980). A 'Winchester school' wall-painting at Nether Wallop, Hampshire. Anglo-Saxon England, 9, 115-136.

Greene, W. C. (Ed. \& trans.) (1960). Saint Augustine: The city of God against the pagans. 7 vols. London: William Heinemann.

Hall, T. N. (1993). Medieval traditions about the site of Judgement. Essays in Medieval Studies, 10, 79-97.

Hellemo, G. (1989). Adventus Domini: Eschatological thought in fourth-century apses and catecheses. Leiden: Brill.

Hill, T. D. (1969). Notes on the eschatology of the Old English Christ III. Neuphilologische Mitteilungen, 70, 672-675.

Hill, T. D. (1971). Further notes on the eschatology of the Old English Christ III. Neuphilologische Mitteilungen, 72, 691-698.

Hill, T. D. (1973). Vision and judgement in the Old English poem Christ III. Studies in Philology, 70(3), 233-242.

James, M. R., \& Minns, E. H. (Eds.). (1905). A descriptive catalogue of the manuscripts in the library of Pembroke College, Cambridge. Cambridge: Cambridge University Press.

Keynes, S. (1985). King Athelstan's books. In M. Lapidge \& H. Gneuss (Eds.), Learning and literature in Anglo-Saxon England: Studies presented to Peter Clemoes (pp. 143-201). Cambridge: Cambridge University Press.

Krapp, G. P., \& Van Kirk Dobbie, E. (Eds.). (1931-1942). The Anglo-Saxon poetic records. New York: Columbia University Press.

Martin, L. T., \& Hurst, D. (Eds. \& trans.). (1991). Bede the Venerable: Homilies on the Gospels. 2 vols. London and Massachusetts: Cistercian Publications.

Meyvaert, P. (1979). Bede and the church paintings at Wearmouth-Jarrow. Anglo-Saxon England, 8, 63-77.

Migne, J. P. (Ed.). (1844-1902). Patrologiae cursus completus. Series Latina. 221 vols in 222. Paris: Migne.

Migne, J. P. (Ed.). (1857-1899). Patrologiae cursus completus. Series Gracea. 161 vols in 166. Paris: Migne. 
Morin, G. (Ed.). (1953). Caesarius arelatensis: Sermones. Corpus christianorum series latina (vol. 103). Turnhout: Brepols.

Mueller, M. (Ed. \& trans.). (1956). Saint Caesarius of Arles: Sermons volume 1 (1-80). Fathers of the church series 31. Washington, D.C.: Catholic University of America Press.

Muir, B. J. (Ed.). (2000). The Exeter anthology of Old English poetry: An edition of Exeter Dean and Chapter MS 3501 (2 Vols, 2nd edn.). Exeter: Exeter University Press.

Murray, J. (1983). A history of ideas and images in Italian art. London: John Murray.

Ó Carragáin, É. (1981). Christ over the beasts and the Agnus Dei: Two multivalent panels on the Ruthwell and Bewcastle Cross. In P. E. Szarmach (Ed.), Sources of Anglo-Saxon culture (pp. 377-403). Kalamazoo: Medieval Institute Publications.

Ó Carragáin, É. (2012). Conversion, justice, and mercy at the parousia: Liturgical apocalypses from eighth-century Northumbria, on the Ruthwell and Bewcastle Cross. Literature and Theology, 26, 367-383.

O'Reilly, J. (1987-1988). Early medieval text and image: The wounded and exalted Christ. Peritia, 6-7, $72-118$

Parks, D. (1984). The 'Lewes group' of wall paintings in Sussex. In R. Allen Brown (Ed.), Anglo-Norman studies VI: Proceedings of the battle conference 1983 (pp. 200-235). Woodbridge, Suffolk: Boydell Press.

Plummer, C. (Ed.) (1896; repr. 1961). Bede's Historia abbatum auctore Baeda, in Venerabilis Baedae opera historica (2 Vols). Oxford: Oxford University Press.

Raw, B. C. (1997). Trinity and incarnation in Anglo-Saxon art and thought. Cambridge: Cambridge University Press.

Raw, B. C. (2004). Pictures: The books of the unlearned? In P. Cavill (Ed.), The Christian tradition in Anglo-Saxon England: Approaches to current teaching and scholarship (pp. 103-120). Cambridge: D. S. Brewer.

Salvador, M. (2006). Architectural metaphors and Christological imagery in the Advent Lyrics: Benedictine propaganda in the Exeter Book? In C. E. Karkov \& N. Howe (Eds.), Conversion and colonization in Anglo-Saxon England (pp. 169-212). Tempe, Arizona: Arizona Center for Medieval and Renaissance Studies.

Schiller, G. (Ed.). (1971). Ikonographie der christlichen Kunst, III: Die Auferstehung und Erhöhung Christi. Gütersloh: Gütersloher Verlagshaus G. Mohn.

Schneelmelchor, W., \& Wilson, R. McL. (Eds. \& trans.). (1991; rev. edn.). The New Testament apocrypha. Louisville: Westminster John Knox Press.

Scragg, D. G. (Ed.). (1992). Vercelli Homilies and related texts. Early English Texts Society o.s. 300. Oxford: Oxford University Press.

Shimomura, S. (2002). Visualizing judgment: Illumination in the Old English Christ III. In T. N. Hall et al. (Eds.), Via crucis: Essays on early medieval sources and ideas in memory of J.E. Cross (pp. 27-49). Morgantown, W.Va: West Virginia University Press.

Swan, M. (1998). The Apocalypse of Thomas in Old English. Leeds Studies in English, n.s., 29, 333-346.

Thomas, D. (2017). The gates of Hell: Invasion and damnation in an anonymous Old English Vigil homily. Leeds Studies in English, n.s., 48, 57-72.

Trahern, J. B., Jr. (1976). Caesarius of Arles and Old English literature: Some contributions and a recapitulation. Anglo-Saxon England, 5, 105-119.

Way, A. (Ed. \& trans.). (1963). Saint Basil: Exegetical homilies. Fathers of the church series 46. Washington, DC: Catholic University of America Press.

Weber, R., et al. (Eds.). (1994). Biblia sacra iuxta vulgatam versionem (4th edn.). Stuttgart: Deutsche Bibelgesellschaft.

Williamson, P. (2010). Medieval ivory carvings: Early Christian to Romanesque. London: V\&A Publishing.

Wormald, F. (1967). Anniversary address. The Antiquaries Journal, 47, 159-165.

Publisher's Note Springer Nature remains neutral with regard to jurisdictional claims in published maps and institutional affiliations. 